\title{
Smoltification and Seawater Adaptation in Coho Salmon (Oncorhynchus kisutch): Plasma Prolactin, Growth Hormone, Thyroid Hormones, and Cortisol
}

\author{
Graham Young, ${ }^{*}$ Björn Th. Björnsson, ${ }^{*}, 1$ Patrick Prunet, $\dagger$ Richard J. Lin, ${ }^{*}$ \\ ANd Howard A. Bern*
}

*Department of Zoology and Cancer Research Laboratory, and Bodega Marine Laboratory, University of California, Berkeley, California 94720; and $\nmid$ Laboratoire de Physiologie des Poissons, INRA,

Campus de Beaulieu, 35042 Rennes, France

Accepted October 18, 1988

\begin{abstract}
The status of circulating growth hormone and prolactin during the parr-smolt transformation and during seawater adaptation of coho salmon (Oncorhynchus kisutch) was investigated in relation to changes in plasma levels of thyroxine, triiodothyronine, and cortisol, and in hypoosmoregulatory ability. Sampling (biweekly or monthly) occurred between early February and October. When peak hypoosmoregulatory ability was achieved (mid-April), one group of fish was acclimated to seawater over a period of $18 \mathrm{hr}$ and was sampled 1,3, and 7 days after the introduction of fish to seawater and biweekly thereafter. Plasma prolactin levels rose steadily from the first sampling date to a peak of $15 \mathrm{ng} / \mathrm{ml}$ in early April, declined rapidly, and remained low until June when a second increase occurred. Prolactin declined to $2 \mathrm{ng} / \mathrm{ml}$ within 1 day of the beginning of seawater adaptation. Growth hormone increased twofold from February to late March, and achieved plateau levels of $20 \mathrm{ng} / \mathrm{ml}$ in the period from mid-April to July and then gradually declined to $10 \mathrm{ng} / \mathrm{ml}$ in September and October. Plasma levels of growth hormone in seawater-acclimated fish were similar to those of freshwater coho, but with larger fluctuations; no increase was apparent during the first week of seawater acclimation. Plasma cortisol and plasma triiodothyronine increased at the same time as plasma growth hormone; increases in plasma thyroxine occurred later. In general, both growth hormone and cortisol levels were elevated when hypoosmoregulatory ability was high. Conversely, prolactin levels generally showed a negative relationship with hypoosmoregulatory ability. (1) 1989 Academic Press, Inc.
\end{abstract}

A number of endocrine changes have now been identified during the parr-smolt transformation (smoltification) of anadromous salmonids. The two most clearly and consistently defined are increased plasma levels of thyroid hormones (Dickhoff $e t$ al., 1978, 1982; Grau et al., 1982; Nagahama et al., 1982; Lindahl et al., 1983; Youngson and Simpson, 1984; Boeuf and Prunet, 1985; Lin et al., 1985, 1988; Virtanen and Soivio, 1985; Yamauchi et al., 1985; Mc-

${ }^{1}$ Current address: Department of Zoophysiology, University of Göteborg, Box 25059 , S-400 31 Göteborg, Sweden.
Cormick et al., 1987b; Prunet et al., 1989) and cortisol (Specker and Schreck, 1982; Barton et al., 1985; Virtanen and Soivio, 1985; Langhorne and Simpson, 1986; Young, 1986) which coincide approximately with a period of enhanced seawater adaptability. Although the precise roles of thyroid hormones and cortisol are as yet incompletely defined, increases in the former may function to synchronize the various developmental events occurring during smoltification (Grau et al., 1982), in addition to their potential involvement in migratory behavior (see Yamauchi et al., 
1985) and other processes (see Dickhoff and Sullivan, 1987). Increasing evidence suggests that cortisol may enhance gill $\mathrm{Na}^{+}, \mathrm{K}^{+}$-ATPase activity in coho salmon, Oncorhynchus kisutch (Richman and Zaugg,1987; Björnsson et al., 1987), and contribute to improved hypoosmoregulatory ability.

Recent studies have demonstrated that the ability of exogenous mammalian and salmonid growth hormones to increase seawater adaptability in salmonids is independent of the growth-promoting effects of these hormones (Bolton et al., 1987) and increased plasma levels of growth hormone have been reported in coho salmon late in smoltification (Sweeting et al., 1985). The role of prolactin in salmonid osmoregulatory physiology is less clear; however, the plasma levels of prolactin after transfer of fish to different salinities (Prunet and Boeuf, 1985; Prunet et al., 1985; Hirano et $a l ., 1987)$ are consistent with the "freshwater-adapting" role ascribed to this hormone in euryhaline teleosts (see Loretz and Bern, 1982; Hirano et al., 1987). Richman et al. (1987b) have reported that plasma prolactin levels peak during smoltification of coho salmon.

In view of the potential importance of these hormones in bringing about physiological changes that are preparatory for seawater entry, the present study was undertaken to document changes in plasma prolactin and growth hormone during smoltification and seawater adaptation of coho salmon in relation to the circulating levels of thyroid hormones and cortisol and hypoosmoregulatory ability. A companion paper (Björnsson et al., 1989) provides details on osmoregulatory changes during smoltification with emphasis on divalent cation regulation and the possible role of calcitonin. Similarly, a third paper in this series (Prunet et al., 1989) reports endocrine changes in the Atlantic salmon, Salmo salar, during smoltification and compares these changes with those occurring in a Pacific salmon, $O$. kisutch.

\section{MATERIALS AND METHODS}

Animals. Yearling coho salmon were obtained from Iron Gate Hatchery, California Department of Fish and Game in December 1986. They were maintained at Bodega Marine Laboratory at the same density at $12-14^{\circ}$ in three identical 2000 -liter concrete raceways supplied with filtered pond water and were fed twice daily with Oregon Moist Pellets at a ration of $2 \%$ body wt/day.

Sampling. Samples were taken every 2 weeks from February to mid-July and monthly thereafter. Blood samples for cortisol and thyroid hormone analysis were obtained from 10 fish captured with one sweep of a net and immediately subjected to buffered tricaine methanesulfonate (MS-222, $200 \mathrm{mg} /$ liter; Sigma, St. Louis, MO) anesthesia (cf. Barton et al., 1985; Young, 1986). After measuring body weight and length, blood was collected from the severed caudal vessels into heparinized microhematocrit tubes, and plasma obtained after centrifugation was immediately frozen on dry ice and stored at $-80^{\circ}$ until analysis. Plasma samples for prolactin and growth hormone measurements were obtained from groups of 10 fish which were stunned by cranial concussion before blood collection. This sampling schedule was maintained until April 15 when the freshwater supply to one raceway was turned off and the seawater supply was turned on, resulting in a complete changeover to $31 \%$ seawater within $18 \mathrm{hr}$. Both freshwater and seawater fish were sampled at 1,3, 7, and 14 days after the beginning of the change to seawater and biweekly thereafter until mid-July when sampling of the seawater-adapted coho was discontinued.

Hormone radioimmunoassays. Prolactin was measured in a homologous assay using the method of Hirano et al. (1985) and Prunet et al. (1985), and growth hormone was measured using the homologous assay of Bolton et al. (1986). Cortisol was measured using the assay described by Redding et al. (1984), as modified by Young (1986). Plasma thyroxine and triiodothyronine levels were determined using the methods of Dickhoff et al. $(1978,1982)$ with minor modifications (Specker and Kobuke, 1987).

Statistical analyses. One-way analysis of variance and a posteriori Student-Newman-Keuls multiple range tests were used to assess the significance of seasonal changes in plasma hormone levels. One-way analysis of variance and a priori Mann-Whitney $U$ tests were used to assess differences between fish in fresh water and in seawater. All tests were performed on an IBM personal computer using CRISP version 3.05A (Crunch, San Francisco, CA). 


\section{RESULTS}

\section{Body Weight, Length, and \\ Condition Factor}

Mean body weight increased in a linear fashion from $20 \mathrm{~g}$ in February to $55 \mathrm{~g}$ in August; a more rapid increase occurred in the last two months of sampling and the mean weight at the final sampling was $90 \mathrm{~g}$. Body length increased from 12.5 to $20 \mathrm{~cm}$ over the course of sampling. Condition factor (weight $\times 100 /$ length $^{3}$ ) was lowest during the period of April-July. Overall, there were no consistent differences in body weight, length, or condition factor between freshwater and seawater coho.

\section{Plasma Cortisol (Fig. 1)}

In February and March, plasma cortisol levels remained stable at about $5 \mathrm{ng} / \mathrm{ml}$. During early April, levels rose significantly $(P<0.05$ compared to values in February and March) to $17 \mathrm{ng} / \mathrm{ml}$ and remained fairly stable (17-27 ng/ml) throughout April and May. At the beginning of June, levels again rose significantly $(P<0.01)$ to $45 \mathrm{ng} / \mathrm{ml}$ but

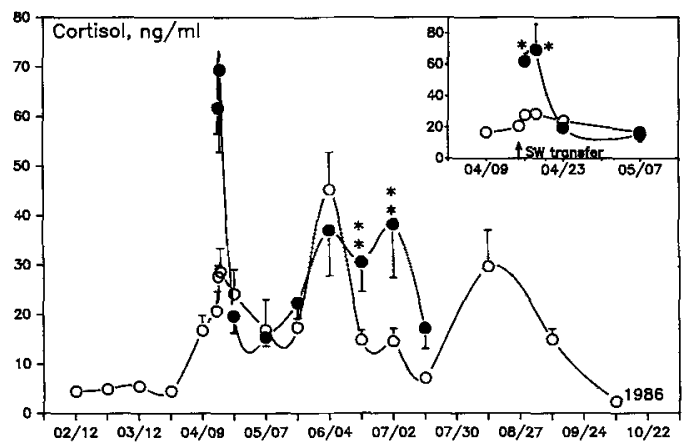

FIG. 1. Changes in plasma cortisol levels (mean and SEM) during the parr-smolt transformation of coho salmon maintained in fresh water (open circles) and during seawater adaptation (closed circles). Insert: Details of changes in plasma cortisol levels $1,3,7$, and 14 days after seawater exposure. Asterisks denote significant differences $\left({ }^{*} P<0.01 ;{ }^{* *} P<0.05\right)$ in levels between freshwater and seawater fish. $n=8-10$ for each point. Absence of standard error bars indicates that the SEM was smaller than the symbol. declined through June and July. In midAugust, levels again rose significantly $(P<$ 0.01 ) to $30 \mathrm{ng} / \mathrm{ml}$ and again progressively declined during the last 2 months of sampling. Plasma cortisol levels were elevated significantly $(P<0.01)$ to $60-70 \mathrm{ng} / \mathrm{ml} 1$ and 3 days after the beginning seawater exposure (April 15) but declined to freshwater values after 7 days. Cortisol levels in seawater coho were generally similar to those of freshwater fish thereafter; however, when levels rose in both groups to a peak in early June, significantly $(P<0.05)$ higher levels were maintained for 1 month in seawater coho in comparison to the decline observed in freshwater fish.

\section{Plasma Thyroxine (Fig. 2)}

Between February and early April, plasma thyroxine levels varied between 4 and 6 $\mathrm{ng} / \mathrm{ml}$; levels increased to about $7.5 \mathrm{ng} / \mathrm{ml}$ on April 15 and by the next day, peak levels of $11 \mathrm{ng} / \mathrm{ml}(P<0.01$ compared to values from February to early April) were achieved. Following a brief but significant $(P<0.01)$ decline to $7.5 \mathrm{ng} / \mathrm{ml}$ on April 18, levels again rose $(P<0.01)$ to $11 \mathrm{ng} / \mathrm{ml}$ on

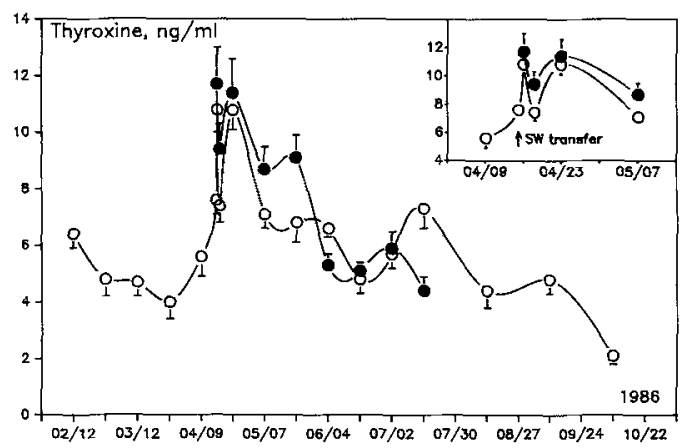

FIG. 2. Changes in plasma thyroxine levels (mean and SEM) during the parr-smolt transformation of coho salmon maintained in fresh water (open circles) and during seawater adaptation (closed circles). Insert: Details of changes in plasma thyroxine levels 1,3 , 7 , and 14 days after seawater exposure. $n=8-10$ for each point. Absence of standard error bars indicates that the SEM was smaller than the symbol. 
April 23. Thereafter, levels declined to between 5 and $7 \mathrm{ng} / \mathrm{ml}$. In fish introduced to seawater on April 15, an essentially similar pattern of plasma thyroxine was found which did not vary significantly from that of the freshwater group.

\section{Plasma Triiodothyronine (Fig. 3)}

The pattern of plasma triiodothyronine levels was similar to that of thyroxine, although the initial increase occurred earlier. A fairly rapid increase occurred from basal levels of $2 \mathrm{ng} / \mathrm{ml}$ in February and March to peak levels $(P<0.05)$ of around $4 \mathrm{ng} / \mathrm{ml}$ in mid-April; levels quickly declined thereafter to a minimum of $1.5 \mathrm{ng} / \mathrm{ml}$ in mid-June and again gradually increased over the next 2 months to $3-4 \mathrm{ng} / \mathrm{ml}$ in September and October. Plasma levels of triiodothyronine in seawater-adapted fish were generally higher, although not significantly so, compared to freshwater coho during the first month in seawater.

\section{Plasma Prolactin (Fig. 4)}

Plasma prolactin levels rose steadily, increasing three-fold from an initial value of 5

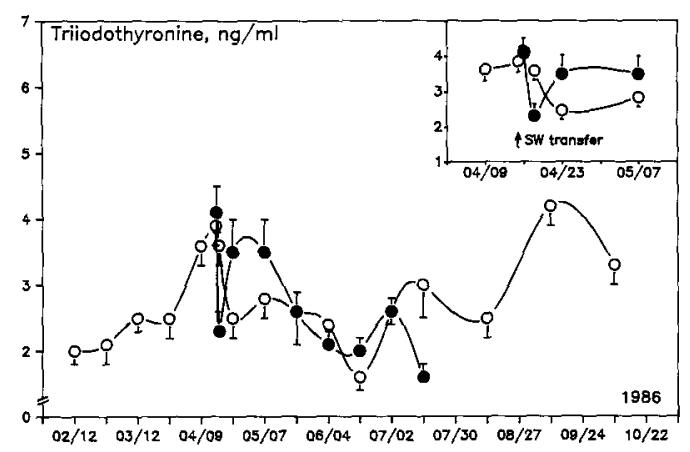

FIG. 3. Changes in plasma triiodothyronine levels (mean and SEM) during the parr-smolt transformation of coho salmon maintained in fresh water (open circles) and during seawater adaptation (closed circles). Insert: Details of changes in plasma triiodothyronine levels $1,3,7$, and 14 days after seawater exposure. $n$ $=8-10$ for each point.

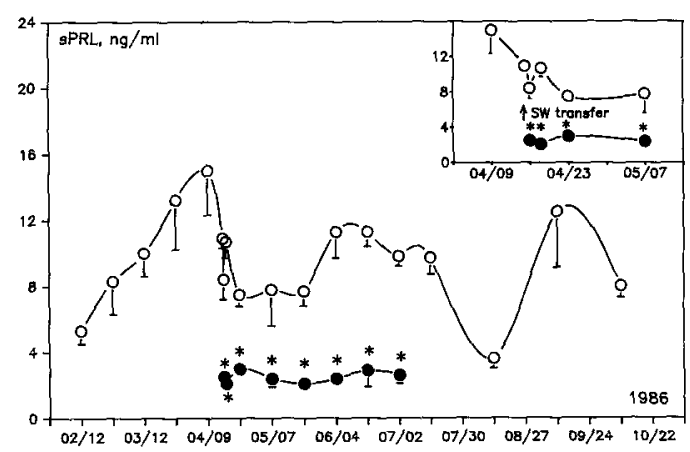

FIG. 4. Changes in plasma prolactin levels (mean and SEM) during the parr-smolt transformation of coho salmon maintained in fresh water (open circles) and during seawater adaptation (closed circles). Insert: Details of changes in plasma prolactin levels 1,3 , 7 , and 14 days after seawater exposure. Asterisks denote significant differences $(P<0.01)$ between levels in freshwater and seawater fish. $n=8-10$ for each point. Absence of standard error bars indicates that the SEM was smaller than the symbol.

$\mathrm{ng} / \mathrm{ml}$ to a peak of $15 \mathrm{ng} / \mathrm{ml}$ on April $9(P<$ 0.01 compared to initial levels). In coho kept exclusively in fresh water, prolactin levels then declined rapidly to $7-8 \mathrm{ng} / \mathrm{ml}$ but increased in June. Following a significant $(P<0.05)$ decline to about $4 \mathrm{ng} / \mathrm{ml}$ in midAugust, levels again rose significantly $(P<$ 0.05 ) to around $8-12 \mathrm{ng} / \mathrm{ml}$ in September and October. Prolactin levels declined rapidly and significantly $(P<0.01)$ to approximately $2 \mathrm{ng} / \mathrm{ml}$ within 1 day of seawater exposure and remained at that low level for the duration of sampling.

\section{Plasma growth hormone (Fig. 5)}

Plasma growth hormone levels rose significantly $(P<0.05)$ from initial values of $6-10 \mathrm{ng} / \mathrm{ml}$ in February and March to 17 $\mathrm{ng} / \mathrm{ml}$ on April 9 but dropped significantly $(P<0.01)$ to $12 \mathrm{ng} / \mathrm{ml} 1$ day before seawater transfer on April 15. Levels in freshwater fish increased thereafter and were maintained in the range of $17-21 \mathrm{ng} / \mathrm{ml}$ until midJuly. Growth hormone concentrations then declined gradually to $10-13 \mathrm{ng} / \mathrm{ml}$ in September and October. No differences in 


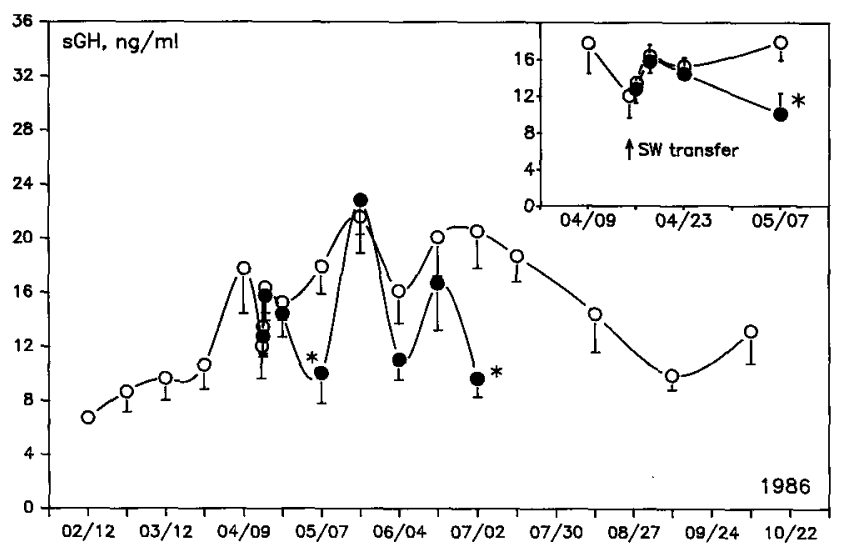

FIG. 5. Changes in plasma growth hormone levels (mean and SEM) during the parr-smolt transformation of coho salmon maintained in fresh water (open circles) and during seawater adaptation (closed circles). Insert: Details of changes in plasma growth hormone levels $1,3,7$, and 14 days after seawater exposure. Asterisks denote significant differences $(P<0.05)$ between freshwater and seawater fish. $n=8-10$ for each point. Absence of standard error bars indicates that the SEM was smaller than the symbol.

growth hormone levels between freshwater and seawater coho were seen during the first week of seawater exposure. Marked fluctuations occurred in seawater coho after that period and levels were significantly lower $(P<0.05)$ in early May and early June. However, maximal growth hormone levels in seawater coho occurred at the same time as in freshwater coho, in midMay.

\section{DISCUSSION}

The approach adopted for this study was intended to (1) document the relationship between changes in plasma prolactin and growth hormone with developmental changes in plasma thyroid hormones and cortisol; (2) study the temporal relationship among these hormones during adaptation to seawater; and (3) by extending sampling of freshwater fish past the time generally analyzed in most studies on coho salmon (January-July), gain information on possible hormonal changes occurring in the postsmoltification period as animals "desmoltify" and lose their ability to osmoregulate efficiently in seawater.
The well-defined increases in plasma thyroid hormones and cortisol during smoltification are in good agreement with other work on this stock of coho salmon (Young, 1986) and with studies on other stocks of the same species (Dickhoff et al., 1978, 1982; Specker and Schreck, 1982; Barton et al., 1985). Plasma thyroxine and plasma triiodothyronine rose relatively rapidly in April and declined during the remainder of the sampling period. However, it is notable that triiodothyronine increased earlier in plasma than in thyroxine. The pattern of plasma cortisol during the parr-smolt transformation consisted of two components: an initial rise during April to a 4- to 6-week plateau coinciding with enhanced hypoosmoregulatory ability (Björnsson et al., 1989), followed by a sharp rise to peak levels in early June, coinciding with decreased hypoosmoregulatory ability (Björnsson et al., 1989). Levels thereafter generally declined, with the exception of a large increase in August. A similar association between the two components of the developmental change in plasma cortisol with changes in hypoosmoregulatory ability has been noted previously (Young, 1986). Al- 
though the smoltification-associated elevation in plasma cortisol coincided with increased gill $\mathrm{Na}^{+}, \mathrm{K}^{+}$-ATPase activity (Björnsson et al., 1989), as previously reported (Young, 1986), and the decrease in gill $\mathrm{Na}^{+}, \mathrm{K}^{+}$-ATPase activity in July occurred at a time of rapidly decreasing cortisol levels, it is clear from the present study that rises in gill $\mathrm{Na}^{+}, \mathrm{K}^{+}$-ATPase activity are not always coupled to rises in plasma cortisol, since increases in the activity of the enzyme, along with a limited improvement in hypoosmoregulatory ability, occurred in October and November (Björnsson et al., 1989) when plasma cortisol levels were low. The significance of increased plasma cortisol levels during smoltification with regard to gill $\mathrm{Na}^{+}, \mathrm{K}^{+}$ATPase activity remains to be fully determined. Langhorne and Simpson (1986) have argued that the high circulating cortisol levels found during smoltification of Atlantic salmon represent a secondary response caused by the development of hypoosmoregulatory ability while the animals are still resident in fresh water and may function to maintain osmoregulatory homeostasis in fresh water. Their argument is based on several kinds of data, including the lack of effect of exogenous cortisol on gill $\mathrm{Na}^{+}, \mathrm{K}^{+}$-ATPase activity (Langdon et al., 1984). However, several differences are apparent between Atlantic salmon and coho salmon, including the often greater relative development of gill $\mathrm{Na}^{+}, \mathrm{K}^{+}$ATPase activity in $S$. salar in fresh water, which reaches values close to those seen in seawater-adapted animals (Langhorne and Simpson, 1986; Prunet et al., 1989); the stimulatory effects of exogenous cortisol on coho salmon gill $\mathrm{Na}^{+}, \mathrm{K}^{+}$-ATPase activity in vivo (Richman and Zaugg, 1987; Björnsson et al., 1987) and in vitro (McCormick et al., 1987a); and, in contrast to coho salmon (Redding et al., 1984; Young, 1985; present study), the absence of elevations in plasma cortisol in Atlantic salmon after transfer to seawater (Nichols and Weisbart,
1985; Langhorne and Simpson, 1986). Together, these studies suggest that hypoosmoregulatory control mechanisms may have evolved differently in coho salmon and Atlantic salmon.

The relatively short-term elevations in plasma cortisol in coho after introduction into seawater are in agreement with previous work (Redding et al., 1984; Young, 1985). One notable finding from the present study is that changes in plasma cortisol in seawater fish after acclimation to seawater generally parallel those found in freshwater fish. Of particular interest was the finding of a second increase in plasma cortisol levels, of longer duration, in seawater fish at the same time that peak levels of plasma cortisol were achieved in freshwater fish in early June, a period when hypoosmoregulatory ability was decreasing. Young (1986) speculated that the second component of the pattern of plasma cortisol seen in freshwater fish may be related to the loss of hypoosmoregulatory ability and reversion of the smolt to a more parr-like condition. The occurrence of elevated cortisol levels at this time in seawater-adapted animals suggests that an endogenous seasonal rhythm of plasma cortisol levels exists in coho salmon, which is maintained irrespective of environment. A question which remains to be answered is whether nonsmoltifying underyearling coho or fish transferred to seawater early in smoltification also display an extended period of elevated plasma cortisol levels which are associated with elevated plasma thyroxine and enhanced hypoosmoregulatory ability in animals undergoing the parr-smolt transformation in fresh water. However, Langhorne and Simpson (1986) found that elevated serum cortisol levels are a specific feature of the parr-smolt transformation in Atlantic salmon, since only smolts displayed cortisol elevations when smolts and nonsmolts of the same age were sampled. Conceivably, the maintenance of a rhythm in plasma cortisol levels in seawater-adapted coho may be related to 
the depletion of lipids and carbohydrates associated with the parr-smolt transformation (Woo et al., 1978): Sheridan (1986) has demonstrated that cortisol promotes lipid mobilization in coho salmon.

Plasma thyroxine and triiodothyronine levels in coho introduced to seawater in April generally paralleled those of freshwater coho. There was no negative effect of the hyperosmotic environment on thyroid hormone levels. Several authors have reported depressed thyroid activity after transfer of coho salmon to seawater early in smoltification (Dickhoff et al., 1982; Folmar et al., 1982; Specker and Schreck, 1984; Specker and Richman, 1984; Specker et al., 1984), but more recent work indicates that transfer of fully smoltified coho to seawater results in enhanced thyroid activity, when the fish are compared with their freshwater counterparts (Specker and Kobuke, 1987). The present results are therefore a further indication that the fish were introduced into seawater at a biologically appropriate time.

Increased plasma levels of prolactin during smoltification of coho salmon have been reported previously (Richman et al., 1987a). The results of the present study, in combination with data from previous years (G. Young, R. S. Nishioka, and P. Prunet, unpublished data) indicate that elevations in circulating prolactin are a general and consistent feature of smoltification of coho salmon. Richman et al. (1987b) found a single peak in plasma prolactin which occurred at a time of elevated plasma thyroxine levels and increased gill $\mathrm{Na}^{+}, \mathrm{K}^{+}$ -ATPase activity; levels rapidly dropped during the extended period of high gill $\mathrm{Na}^{+}, \mathrm{K}^{+}$-ATPase activity. However, prolactin rose earlier in the present study, before the period of elevated thyroxine levels, suggesting that the relationship noted previously between thyroxine and prolactin may not be causal. This is in agreement with experimental data showing a lack of effect of elevated thyroxine levels on pro- lactin levels in coho salmon early in smoltification or in coho postsmolts (G. Young and $P$. Prunet, unpublished data). It is possible that earlier changes in prolactin were not identified in the study of Richman et al. (1987a) because sampling was not started until mid-March. In the present study, prolactin levels remained relatively low and stable during the period of elevated cortisol levels in April to early July. Furthermore, the tendency for prolactin levels to rise after that period occurred when plasma cortisol levels approached initial basal levels, and the abrupt drop in prolactin from 14 $\mathrm{ng} / \mathrm{ml}$ in mid-July to $3 \mathrm{ng} / \mathrm{ml}$ in mid-August coincided with a relatively large increase in circulating cortisol, from 7 to $30 \mathrm{ng} / \mathrm{ml}$. Clearly, the relationship between prolactin and cortisol in salmonids needs experimental analysis.

Prolactin levels rapidly declined to baseline within 1 day of the introduction of coho to seawater and remained low throughout the remainder of the sampling period. This finding is consistent with the notion that in coho salmon, as in other teleosts, prolactin is involved in maintaining homeostasis in fresh water (see Loretz and Bern, 1982; Hirano et al., 1987; Hasaegawa et al., 1987). However, prolactin appears not to be mandatory for freshwater survival of salmonids, since only minor changes occur in plasma $\mathrm{Na}^{+}$in fresh water after hypophysectomy of several salmonid species (Donaldson and McBride, 1967; Komourdjian and Idler, 1977; Björnsson and Hansson, 1983; Komourdjian, 1984; Nishioka et al., 1987; Richman et al., 1987a).

The significance of elevations in plasma prolactin levels during smoltification of coho salmon has not yet been resolved. On the basis of data from euryhaline species, elevated prolactin may function to prevent excessive ion loss in fresh water as seawater-adaptive mechanisms develop. However, it is difficult to reconcile this possibility with the rapid decrease in plasma prolactin levels that occurred in April, when 
hypoosmoregulatory ability was maximal. No ion loss from freshwater coho was apparent during this period (Björnsson et al., 1989), although there have been reports of this occurring in other studies (see Richman et al., 1987b). Sheridan (1986) has demonstrated that ovine prolactin stimulates lipid mobilization in the early stages of smoltification of coho salmon, which suggests that the elevations in plasma prolactin may also serve to stimulate some of the changes in lipid and carbohydrate metabolism characteristic of the parr-smolt transformation. Prunet et al. (1989) found that plasma prolactin decreased during smoltification of Atlantic salmon with no evidence of the type of increase observed in coho salmon, again suggesting that differences have evolved between these two species in the endocrine regulation of smoltification. However, in both the coho (present study) and the Atlantic salmon (Prunet et al., 1989), elevations in gill $\mathrm{Na}^{+}, \mathrm{K}^{+}$-ATPase activity generally occurred when plasma prolactin levels were low and vice versa. Whether this relationship is causal remains to be explored.

In the present study, growth hormone levels began rising relatively early in development, concomitant with increasing hypoosmoregulatory ability, and remained high for a 3-month period. Seawater transfer did not induce elevations in growth hormone levels; rather, changes in growth hormone levels in seawater fish paralleled those in freshwater coho during the first week after transfer. The pattern seen thereafter in seawater fish had some similarity to that in freshwater fish, with the notable exception of the relatively large fluctuations in levels in seawater-adapted fish. A similar pattern of increases in plasma levels of growth hormone has recently been reported for Atlantic salmon (Prunet et al., 1989). These studies further substantiate the experimental evidence showing that mammalian and teleostean growth hormones improve the hypoosmoregulatory ability in several species of salmonids (Komourdjian et al., 1976; Clarke et al., 1977; Miwa and Inui, 1985; Bolton et al., 1987) and enhance gill $\mathrm{Na}^{+}, \mathrm{K}^{+}$-ATPase activity in coho salmon (Richman and Zaugg, 1987; Björnsson et al., 1987), and suggest that increased circulating growth hormone may be a consistent feature of the parr-smolt transformation in both coho salmon and Atlantic salmon. Increased plasma growth hormone levels have been reported in chum salmon, O. keta, 6 and $12 \mathrm{hr}$ after their introduction into seawater (Hirano et al., 1987; Hasegawa et al., 1987). Sweeting et al. (1985) reported increasing plasma growth hormone levels relatively late in the parr-smolt transformation and increased growth hormone levels 12 and $24 \mathrm{hr}$ after exposure of coho to seawater. Direct comparisons with the data obtained in the present study are not possible since other hormonal changes or changes in hypoosmoregulatory ability were not assessed: their seawater transfer experiment was apparently conducted relatively early in smoltification on coho of about $15-20 \mathrm{~g}$ body wt. There are several possible explanations for the lack of change in plasma growth hormone levels in coho salmon after transfer to seawater in the present study: adaptive changes in growth hormone may occur before $24 \mathrm{hr}$ after transfer; coho which have already achieved peak hypoosmoregulatory ability may not require further elevations in plasma growth hormone to adapt rapidly and successfully to the hyperosmotic environment; the relatively slow replacement of fresh water with seawater during the first $24 \mathrm{hr}$ of adaptation may have reduced osmotic stress which might otherwise stimulate growth hormone secretion; or metabolic clearance rate and/or receptor numbers may increase rapidly and substantially after exposure of coho to seawater. The increases in plasma growth hormone levels coincided with those in plasma cortisol. There is substantial evidence for a close functional relationship among growth hormone, thyroid hor- 
mones, and corticosteroids in mammals. However, the evidence in teleosts is largely indirect; cortisol stimulates growth hormone secretion by the pituitary of tilapia (Oreochromis mossambicus) in vitro (Nishioka et al., 1985), and both growth hormone and thyroid hormones have stimulatory effects on the interrenal of coho salmon (Young, 1988; Young and Lin, 1988). Growth hormone has been demonstrated to have both hyperglycemic (Sweeting et al., 1985) and lipolytic (Sheridan, 1986) effects in coho salmon and may play a role in the metabolic changes occurring during smoltification.

In summary, the first of the hormones we measured to display distinct changes as the animals enter the period of smoltification is prolactin. A possibly critical period in development occurred in early April when prolactin levels dropped rapidly, coincident with increases in growth hormone, thyroid hormones, and cortisol and in gill $\mathrm{Na}^{+}, \mathrm{K}^{+}$-ATPase activity (Björnsson $e t$ al., 1989). Growing evidence indicates that growth hormone serves a seawateradaptive role in salmonids. The role played by prolactin in the smoltification of coho salmon remains ill defined, although the generally inverse relationship observed between plasma prolactin levels and gill $\mathrm{Na}^{+}, \mathrm{K}^{+}$-ATPase activity deserves experimental investigation. Recent data from the masu salmon (O. masou) are largely similar to those reported herein for the coho salmon: a growth hormone peak occurs at about the same time as the thyroxine peak, and a prolactin peak precedes both $(\mathrm{M}$. Ikuta, K. Aida, and T. Hirano, personal communication).

\section{ACKNOWLEDGMENTS}

We thank Drs. Tetsuya Hirano, Hiroshi Kawauchi, and Tsuyoshi Ogasawara both for the provision of growth hormone and antisera, and, together with Dr. Jonathan P. Bolton, for their invaluable advice on setting up the growth hormone radioimmunoassay. Drs. Stephen D. McCormick and Richard S. Nishioka gave invaluable counsel on various aspects of this work, and Brian Williams, Wayne Leong, Kenneth Takamura, Anne McBride, and Kevin Mark provided excellent technical assistance. Coho salmon were provided by the California Department of Fish and Game. This work is a result of work sponsored in part by NOAA, National Sea Grant College Program, Department of Commerce, under Grant NA85AA-D-SG140, through the California Sea Grant College Program, in part by the California State Resources Agency, projects R/F-101 and R/F-117, in part by NSF Grant DCB84-05249, in part by a grant from the Icelandic Science Foundation to B.Th.B., and in part by a NATO grant to P.P. An award of a Swedish Natural Science Research Council postdoctoral fellowship to B.Th.B. is also acknowledged. The U.S. government is authorized to reproduce and distribute for governmental purposes.

\section{REFERENCES}

Barton, B. A., Schreck, C. B., Ewing, R. D., Hemmingsen, A. R., and Patinõ, R. (1985). Changes in plasma cortisol during stress and smoltification in coho salmon, Oncorhynchus kisutch. Gen. Comp. Endocrinol. 59, 468-471.

Björnsson, B. Th., and Hansson, T. (1983). Effects of hypophysectomy on the plasma ionic and osmotic balance in rainbow trout, Salmo gairdneri. Gen. Comp. Endocrinol. 49, 240-247.

Björnsson, B. Th., Yamauchi, K., Nishioka, R. S., Deftos, L. J., and Bern, H. A. (1987). Effects of hypophysectomy and subsequent hormonal replacement therapy on hormonal and osmoregulatory status of coho salmon, Oncorhynchus kisutch. Gen. Comp. Endocrinol. 68, 421-430.

Björnsson, B. Th., Young, G., Lin, R. J., Deftos, L. J., and Bern, H. A. (1989). Smoltification and seawater adaptation in coho salmon (Oncorhynchus kisutch): Plasma calcium regulation, osmoregulation and calcitonin. Gen. Comp. Endocrinol. 74, 346-354.

Boeuf, G., and Prunet, P. (1985). Measurement of gill $\left(\mathrm{Na}^{+}-\mathrm{K}^{+}\right)$-ATPase activity and plasma thyroid hormones during smoltification in Atlantic salmon (Salmo salar L.). Aquaculture 45, 11-119.

Bolton, J. P., Collie, N. L., Kawauchi, H., and Hirano, T. (1987). Osmoregulatory actions of growth hormone in rainbow trout (Salmo gairdneri). J. Endocrinol. 112, 63-68.

Bolton, J. P., Takahashi, A., Kawauchi, H., Kubota, J., and Hirano, T. (1986). Development and validation of a salmon growth hormone radioimmunoassay. Gen. Comp. Endocrinol. 62, 230-238.

Clarke, W. C., Farmer, S. W., and Hartwell, K. M. (1977). Effect of teleost growth hormone on growth of Tilapia mossambica and on growth and 
seawater adaptation of sockeye salmon (Oncorhynchus nerka). Gen. Comp. Endocrinol. 33, 174-178.

Clarke, W. C., and Nagahama, Y. (1977). Effect of premature transfer to sea water on growth and morphology of the pituitary, thyroid, pancreas and interrenal in juvenile coho salmon (Oncorhynchus kisutch). Canad. J. Zool. 55, 1620-1630.

Dickhoff, W. W., Folmar, L. C., and Gorbman, A. (1978). Changes in plasma thyroxine during smoltification of coho salmon, Oncorhynchus kisutch. Gen. Comp. Endocrinol. 36, 229-232.

Dickhoff, W. W., Folmar, L. C., Mighell, J. L., and Mahnken, C. V. W. (1982). Plasma thyroid hormones during smoltification of yearling and underyearling coho and yearling chinook salmon and steelhead trout. Aquaculture 28, 39-48.

Dickhoff, W. W., and Sullivan, C. V. (1987). Involvement of the thyroid gland in smoltification, with special reference to metabolic and developmental processes. Amer. Fish. Soc. Symp. 1, 197-210.

Donaldson, E. M., and McBride, J. R. (1967). The effects of hypophysectomy in the rainbow trout Salmo gairdneri (Rich.) with special reference to the pituitary-interrenal axis. Gen. Comp. Endocrinol. 9, 93-101.

Folmar, L. C., Dickhoff, W. W., Mahnken, C. V. W., and Waknitz, F. W. (1982). Stunting and parrreversion during smoltification of coho salmon (Oncorhynchus kisutch). Aquaculture 28, 91-104.

Grau, E. G., Specker, J. L., Nishioka, R. S., and Bern, H. A. (1982). Factors determining the occurrence of the surge in thyroid activity in salmon during smoltification. Aquaculture 28, 49-57.

Hasegawa, S., Hirano, T., Ogasawara, T., Iwata, M., Akiyama, T., and Arai, S. (1987). Osmoregulatory ability of chum salmon, Oncorhynchus keta, reared in fresh water for prolonged periods. Fish Physiol. Biochem. 4, 101-110.

Hirano, T., Ogasawara, T., Bolton, J. P., Collie, N. L., Hasegawa, S., and Iwata, M. (1987). Osmoregulatory role of prolactin in lower vertebrates. In "Comparative Physiology of Environmental Adaptations"' (R. Kirsch and B. Lahlou, Eds.), pp. 112-124. Karger, Basel.

Hirano, T., Prunet, P., Kawauchi, H., Takahashi, A., Kubota, J., Nishioka, R. S., Bern, H. A., Takada, K., and Ishii, S. (1985). Development and validation of a salmon prolactin radioimmunoassay. Gen. Comp. Endocrinol. 59, 266-276.

Komourdjian, M. P. (1984). Monovalent plasma ion regulation in the hypophysectomized Atlantic salmon. Gen. Comp. Endocrinol. 56, 278-282.

Komourdjian, M. P., and Idler, D. R. (1977). Hypophysectomy of rainbow trout, Salmo gairdneri, and its effects on plasmatic sodium regulation. Gen. Comp. Endocrinol. 32, 536-542.
Komourdjian, M. P., Saunders, R. L., and Fenwick, J. C. (1976). The effect of porcine somatotropin on growth, and survival in seawater of Atlantic salmon (Salmo salar) parr. Canad. J. Zool. 54, 531-535.

Langdon, J. S., Thorpe, J. E., and Roberts, R. J. (1984). Effects of cortisol and ACTH on gill $\mathrm{Na}^{+} / \mathrm{K}^{+}$-ATPase, SDH and chloride cells in juvenile Atlantic salmon, Salmo salar L. Comp. Biochem. Physiol. A 77, 9-12.

Langhorne, P., and Simpson, T. H. (1986). The interrelationship of cortisol, gill $(\mathrm{Na}+\mathrm{K})$ ATPase, and homeostasis during the parr-smolt transformation of Atlantic salmon (Salmo salar L.). Gen. Comp. Endocrinol. 61, 203-213.

Lin, R. J., Cross, T. F., Mills, C. P. R., Nishioka, R. S., Grau, E. G., and Bern, H. A. (1988). Changes in plasma thyroxine levels during smoltification in hatchery reared one-year and twoyear Atlantic salmon (Salmo salar). Aquaculture, 74, 369-378.

Lin, R. J., Rivas, R. J., Grau, E. G., Nishioka, R. S., and Bern, H. A. (1985). Effect of feeding triiodothyronine $\left(\mathrm{T}_{3}\right)$ on thyroxin $\left(\mathrm{T}_{4}\right)$ levels in the steelhead trout, Salmo gairdneri. Aquaculture 45, 133142.

Lindahl, K., Lindquist, H., and Rydivik, M. (1983). Plasma thyroxine levels and thyroid gland histology in Baltic salmon (Salmo salar L.) during smoltification. Canad. J. Zool. 61, 1954-1958.

Loretz, C. A., and Bern, H. A. (1982). Prolactin and osmoregulation in vertebrates. Neuroendocrinology 35, 292-304.

McCormick, S. D., Nishioka, R. S., and Bern, H. A. (1987a). In vitro corticoid and growth hormone regulation of $\mathrm{Na}^{+}, \mathrm{K}^{+}$-ATPase activity in gill tissue of coho salmon. Amer. Zool. 27, 74A.

McCormick, S. D., Saunders, R. L., Henderson, E. B., and Harmon, P. R. (1987b). Photoperiod control of parr-smolt transformation in Atlantic salmon (Salmo salar): Changes in salinity tolerance, gill $\mathrm{Na}^{+}, \mathrm{K}^{+}$-ATPase activity, and plasma thyroid hormones. Canad. J. Fish. Aquat. Sci. 44, 1462-1468.

Miwa, S., and Inui, Y. (1985). Effects of L-thyroxine and ovine growth hormone on smoltification of amago salmon (Oncorhynchus rhodurus). Gen. Comp. Endocrinol. 58, 436-442.

Nagahama, Y., Adachi, S., Tashiro, F., and Grau, E. G. (1982). Some endocrine factors affecting the development of seawater tolerance during the parr-smolt transformation of the amago salmon (Oncorhynchus rhodurus). Aquaculture 28, 81-91.

Nichols, D. J., and Weisbart, M. (1985). Cortisol dynamics during seawater adaptation of Atlantic salmon Salmo salar. Amer. J. Physiol. 248, R651R659. 
Nishioka, R. S., Bern, H. A., Lai, K. V., Nagahama, Y., and Grau, E. G. (1982). Changes in the endocrine organs of coho salmon during normal and abnormal smoltification-An electron microscope study. Aquaculture 28, 21-38.

Nishioka, R. S., Grau, E. G., and Bern, H. A. (1985). In vitro release of growth hormone from the pituitary gland of tilapia, Oreochromis mossambicus. Gen. Comp. Endocrinol. 60, 90-94.

Nishioka, R. S., Richman, N. H., Young, G., Prunet, P., and Bern, H. A. (1987). Hypophysectomy of coho salmon (Oncorhynchus kisutch) and survival in fresh water and seawater. Aquaculture 65, 343352.

Prunet, P., and Boeuf, G. (1985). Plasma prolactin level during transfer of rainbow trout (Salmo gairdneri) and Atlantic salmon (Salmo salar) from fresh water to sea water. Aquaculture 45, 167176.

Prunet, P., Boeuf, G., Bolton, J. P., and Young, G. (1989). Smoltification and seawater adaptation in Atlantic salmon (Salmo salar): Plasma prolactin, growth hormone, and thyroid hormones. Gen. Comp. Endocrinol. 74, 355-364.

Prunet, P., Boeuf, G., and Houdebine, L. M. (1985). Plasma and pituitary prolactin levels in rainbow trout during adaptation to different salinities. $J$. Exp. Zool. 235, 187-196.

Redding, J. M., Schreck, C. B., Birks, E. K., and Ewing, R. D. (1984). Cortisol and its effects on plasma thyroid hormone and electrolyte concentrations in fresh water and during seawater acclimation in yearling coho salmon, Oncorhynchus kisutch. Gen. Comp. Endocrinol. 56, 146-155.

Richman, N. H., Nishioka, R. S., Young, G., and Bern, H. A. (1987a). Effects of cortisol and growth hormone replacement on osmoregulation in hypophysectomized coho salmon (Oncorhynchus kisutch). Gen. Comp. Endocrinol. 67, 194 201.

Richman, N. H., Tai de Diaz, S., Nishioka, R. S., Prunet, P., and Bern, H. A. (1987b). Osmoregulatory and endocrine relationships with chloride cell morphology and density during smoltification in coho salmon (Oncorhynchus kisutch). Aquaculture 60, 265-285.

Richman, N. H., and Zaugg, W. S. (1987). Effects of cortisol and growth hormone on osmoregulation in pre- and desmoltified coho salmon (Oncorhynchus kisutch). Gen. Comp. Endocrinol. 65, 189198.

Sheridan, M. (1986). Effects of thyroxin, cortisol, growth hormone, and prolactin on lipid metabolism of coho salmon, Oncorhynchus kisutch, during smoltification. Gen. Comp. Endocrinol. 64, 220-238.
Specker, J. L., DiStefano, J. J., III, Grau, E. G., Nishioka, R. S., and Bern, H. A. (1984). Development-associated changes in thyroxine kinetics in juvenile salmon. Endocrinology 115, 399-406.

Specker, J. L., and Kobuke, L. (1987). Seawateracclimation and the thyroidal response to thyrotropin in juvenile coho salmon (Oncorhynchus kisutch). J. Exp. Zool. 241, 327-332.

Specker, J. L., and Richman, N. H. (1984). Environmental salinity and the thyroidal response to thyrotropin in juvenile coho salmon. J. Exp. Zool. 230, 327-332.

Specker, J. L., and Schreck, C. B. (1982). Changes in plasma corticosteroids during smoltification of coho salmon, Oncorhynchus kisutch. Gen. Comp. Endocrinol. 46, 53-58.

Sweeting, R. M., Wagner, G. F., and McKeown, B. A. (1985). Changes in plasma glucose, amino acid nitrogen and growth hormone during smoltification and seawater adaptation in coho salmon, Oncorhynchus kisutch. Aquaculture 45, 185-197.

Virtanen, E., and Soivio, A. (1985). The patterns of $\mathrm{T}_{3}, \mathrm{~T}_{4}$, cortisol and $\mathrm{Na}^{+}-\mathrm{K}^{+}$-ATPase during smoltification of hatchery-reared Salmo salar and comparison with wild smolts. Aquaculture 45, 97109.

Woo, N. Y. S., Bern, H. A., and Nishioka, R. S. (1978). Changes in body composition associated with smoltification and premature transfer in seawater of coho salmon (Oncorhynchus kisutch) and king salmon (O. tshawytscha). J. Fish. Biol. 13, $421-428$.

Yamauchi, Y., Ban, M., Kasahara, N., Izumi, T., Kojima, H., and Harako, T. (1985). Physiological and behavioral changes occurring during smoltification in the masu salmon, Oncorhynchus masou. Aquaculture 45, 227-235.

Young, G. (1985). In vitro studies on interrenal gland activity during smoltification of coho salmon. Aquaculture 45, 391-392.

Young, G. (1986). Cortisol secretion in vitro by the interrenal of coho salmon (Oncorhynchus kisutch) during smoltification: Relationship with plasma thyroxine and plasma cortisol. Gen. Comp. Endocrinol. 63, 191-200.

Young, G. (1988). Enhanced response of the interrenal of coho salmon (Oncorhynchus kisutch) to ACTH after growth hormone treatment in vivo and in vitro. Gen. Comp. Endocrinol. 71, 85-92.

Young, G., and Lin, R. J. (1988). Response of the interrenal to adrenocorticotropin after short term thyroxine treatment of coho salmon (Oncorhynchus kisutch). J. Exp. Zool. 245, 53-58.

Youngson, A. F., and Simpson, T. H. (1984). Changes in serum thyroxine levels during smolting in captive and wild Atlantic salmon, Salmo salar L. J. Fish Biol. 24, 29-39. 